Diterima : 8-5-2020 Revisi : 20-6-2020Ｄipublikasi : 25-6-2020

\title{
UPAYA PENERAPAN MEDIA YOUTUBE DALAM PENINGKATAN KETERAMPILAN MENYIMAK UNSUR CERITA LISAN
}

\author{
Syafrudin Nugroho, S.Pd \\ SD Muhammadiyah Karangharjo \\ Jl. Kaliajir Kidul, Bedilan, Kalitirto, Kec Berbah Kab Sleman, Indonesia \\ Pos-el:nugmuharjo@gmail.com
}

\begin{abstract}
It is motivated by a corona pandemic that makes students study at home and their low ability to listen to elementary students. This study attempts to describe the improvement of listening skills in identifying verbal stories through YouTube. The research method used is descriptive qualitative. The study was conducted at Muhammadiyah Karangharjo Elementary School with a sample of grade III students totaling 27 students. The results of this study, an increase in students' listening skills using Youtube media.
\end{abstract}

Keywords : verbal stories, Youtube

\begin{abstract}
Abstrak
Dilatarbelakangi oleh pandemi corona sehingga membuat siswa belajar di rumah dan rendahnya kemampuan menyimak siswa sekolah dasar. Penelitian ini berupaya mendeskripsikan tentang peningkatan keterampilan menyimak dalam mengidentifikasi unsur cerita lisan melalui media youtube.Metode penelitian yang digunakan adalah deskriptif kualitatif. Penelitian dilakukan di SD Muhammadiyah Karangharjo dengan sampel siswa kelas III sebanyak 27 siswa. Hasil dari penelitian ini, terjadi peningkatan dalam keterampilan menyimak siswa menggunakan media Youtube.
\end{abstract}

Kata-kata Kunci : cerita lisan, youtube

\section{PENDAHULUAN}

Tahun 2020, dunia digemparkan dengan persebaran virus Corona yang membuat pandemik di seluruh dunia. Pemerintah Indonesia pun menginstruksikan supaya kegiatan belajar mengajar dilakukan di rumah sebagai upaya mencegah penularan virus corona atau covid-19. Pemerintah 
pun mengarahkan untuk bekerja di rumah, belajar di rumah dan beribadah di rumah.

Dalam hal proses pendidikan pembelajaran dalam jaringan (daring) atau pembelajaran jarak jauh dilaksanakan untuk memberikan pengalaman belajar yang bermakna bagi siswa. Pembelajaran dalam jaringan (daring) ini sesuai dengan perkembangan Revolusi Industri 4.0. pembelajaran diiringi perkembangan teknologi dan informasi yang begitu cepat.

Komunikasi merupakan sebuah proses yang terjadi dalam kehidupan setiap manusia seharihari antarindividu sampai menggunakan media yang biasa dikenal dengan komunikasi massa (Damayanti, 2010). Komunikasi bermedia juga berdasarkan teknologi, pola penyebaran, sampai pada bagaimana khalayak mengakses media lambat laun semakin berkembang sehingga dikenal dengan media lama (old media) dan media baru (new media). Jadi, komunikasi bermedia menggunakan media baru dalam bentuk internet dan media sosial mulai menggeser posisi media lama dalam penyampaian informasi. Media sosial bisa diakses kapan pun dan dimana pun dan memiliki sumber tanpa batas membuat posisinya menjadi lebih mendominasi. Misalnya, media televisi yang menyampaikan informasi secara audio visual mulai bersaing dengan kehadiran Youtube. Salah satu media yang sudah akrab dengan siswa adalah konten Youtube. Siswa sudah terbiasa dengan gadget dan internet yang sesuai perkembangan zaman sekarang ini.

Menilik ke belakang, pada awal kehidupan manusia lebih dulu belajar menyimak kemudian berbicara membaca dan menulis.Menyimak sebagai salah satu kegiatan berbahasa merupakan keterampilan yang cukup mendasar dalam aktivitas berkomunikasi. Dalam kehidupan manusia selalu dituntut untuk menyimak baik dilingkungan keluarga sekolah maupun masyarakat. Oleh karena itu, menyimak lebih banyak dari pada kegiatan berbahasa yang lain.

Sesuai dengan kurikulum kelas III SD semester dua pada kompetensi dasar mengidentifikasi unsur cerita (tokoh, tema, latar, amanat). Menyikapi hal tersebut peneliti tertarik untuk melakukan penelitian pada siswa kelas III SD Muhammadiyah Karangharho. Sebagai seorang guru harus mampu memilih media-media mengajar yang tepat dan cocok bagi anak didiknya supaya kegiatan belajar mengajarnya bisa berjalan dengan baik, sempurna dan dapat mencapai hasil yang diinginkan. Sebab bila proses belajar mengajar dapat berjalan lancar akan lebih bisa mendorong serta mengembangkan kreativitas kemampuan dalam mengajar.

Peneliti mengamati berbagai bentuk masalah pembelajaran yang 
diantaranya adalah rendahnya tingkat kemampuaan siswa dalam menceritakan kembali hasil menyimak karena siswa tidak memiliki kepercayaan diri untuk mengungkapkan ide dan pikirannya, rendahnya motivasi untuk menyelesaikan tugas rumah secara mandiri, dan rendahnya tanggungjawab moral ketika mendapatkan nilai rendah.

Peneliti

berusaha menerapkan salah satu media alternatif untuk menumbuhkan kemauan dan keterampilan menyimak siswa yaitu dengan media Youtube.Penggunaan media Youtube dalam pembelajaran menyimak cerita dapat meningkatkan rasa ingin tahu dan minat siswa maka dirumuskan sebuah permasalahan Bagaimana penggunaan media Youtube dalam pembelajaran menyimak cerita pada siswa kelas III SD Muhammadiyah Karangharjo?

Dalam pembelajaran anak Sekolah Dasar terdapat Cerita Fiksi Anak. Hakikat Cerita Fiksi Anak sebagai sebuah karya sastra yang menampilkan cerita tentang misteri kehidupan.Isi cerita dijalin dalam sebuah rangkaian alur yang menampilkan berbagai peristiwa dan tokoh yang jalin menjalin secara serasi yang dikemas dalam bahasa narasi dan dialog.

Dalam menjalin sebuah cerita anak terdapat beberapa unsur.Tokoh cerita adalah sarana strategis untuk memberi tujuan pendidikan yang dimaksud dalam
cerita.Alur cerita berupa alur berkembang dari bagian awal, tengah dan akhir cerita atau disebut juga perkenalan pertikaian dan penyelesaian.Tema sebagai gagasan pengikat cerita mengikat berbagai unsur intrinsik yang membangun cerita hingga tampil sebagai sebuah kesatupaduan yang harmonis.Moral yakni suatu yang ingin disampaikan penulis kepada pembaca.

\section{METODE PENELITIAN}

Penelitian ini menggunakan metode deskriptif kualitatif. Tujuan penelitian ini adalah memperoleh paparan yang objektif mengenai peningkatan kemampuan menyimak cerita melalui media Youtube siswa kelas III SD Muhammadiyah Karangharjo Yogyakarta.

Berdasarkan tujuan di atas, Suharsimi Arikunto (2002:309) menyatakan bahwa penelitian deskriptif merupakan penelitian untuk mengumpulkan informasi mengenai status suatu gejala yang ada, yaitu keadaan gejala menurut apa adanya pada saat penelitian dilakukan. Karena penelitian ini mempunyai tujuan memperoleh data secara sahih, cermat, akurat, dan lengkap. Dari data yang terkumpul kemudian diperiksa, diklasifikasikan, dianalisis, dan dideskripsikan. Hasil analisisnya merupakan deskripsi dari peningkatan kemampuan menyimak cerita dengan media youtube pada siswa.

Penelitian dilaksanakan pada akhir bulan Maret sampai dengan 
bulan April 2020 pada masa belajar di rumah. Penelitian dilaksanakan pada siswa SD Muhammadiyah Karangharjo yang berjumlah 27 siswa.

Teknik Pengumpulan Data yang digunakan Observasi atau disebut juga dengan pengamatan meliputi kegiatan pemusatan perhatian terhadap suatu objek dengan menggunakan seluruh alat indra. Dalam penelitian ini, penulis menggunakan observasi sistematis dan pengamatan tidak langsung yang dilakukan dengan perantara video siswa belajar di rumah.

\section{HASIL PENELITIAN DAN PEMBAHASAN}

Selama ini, kemampuan menyimak cerita dalam kurang mendapat perhatian dari sekolah khususnya guru bahasa Indonesia. Seharusnya keterampilan tersebut lebih diperhatikan dan diangkat kemampuannya karena dengan itu siswa akan dapat mengembangkan dua kemampuan sekaligus, yakni kemampuan berbicara dan kemampuan mengalirkan imajinasi atau ide pikiran.

$$
\text { Pada hakikatnya, }
$$

keterampilan tersebut menjadi sesuatu yang perlu dipupuk sejak dini. Kegiatan tersebut membutuhkan pengetahuan dan cara-cara khusus sehingga sejak awal hendaknya ditanamkan bagaimana cara berbicara dan berhasil bercerita yang benar pada diri siswa sehingga kelak dia dapat berkarya dan membawa diri dalam pergaulan lebih luas dengan kemampuan berbicaranya.

Mengingat begitu besar peranan kegiatan tersebut dalam kehidupan, maka penulis berkeinginan untuk meningkatkan kemampuan siswa dalam bercerita dengan yang dekat dengan siswa yaitu media Youtube.

Prosedur pembelajaran menyimak cerita menggunakan media youtube di kelas III SD Muhammadiyah Karangharjo diuraikan berdasarkan siklus-siklus tindakan pembelajaran.

a. Kegiatan Awal

Pada kegiatan ini difokuskan pada kegiatan menjelaskan unsur cerita. Kegiatan ini diawali dengan :

1 Guru mengadakan presensi untuk mengetahui kehadiran siswa melalui grup Whattsapp

2 Kemudian memberikan motivasi dan menanyakan cerita - cerita apa saja yang pernah didengar oleh anak - anak

3 Pada saat guru menanyakan cerita apa yang pernah didengar, siswa tampak ramai, siswa bersahut sahutan menjawabnya

b. Kegiatan Inti

Pada kegiatan ini setelah pemberian motivasi kemudian guru menjelaskan materi tentang unsurunsur dari suatu cerita.Kemudian guru memberikan link satu cerita yang ada di Youtube dengan judul "Timun Emas" Siswa menyimak cerita tersebut melalui Hp masingmasing.Kemudian

guru 
memberikan soal mengenai unsur cerita.Siswa mengerjakan soal dalam rentang waktu.Jawaban dikirim melalui pesan Whatssapp. Guru melakukan pembahasan soal.

\section{c. Kegiatan Penutup}

Guru melakukan refleksi dan memberikan simpulan mengenai cerita Timun Emas.

Berdasarkan aktivitas siswa yang diperoleh dari simakan 1 maka diperoleh diperoleh nilai 74,9 aktivitas siswa mendapatkan nilai baik dan cukup. Tetapi rata- rata nilai yang didapat pada siklus 1 adalah nilai yang kurang hal ini disebabkan antara lain :Siswa belum terbiasa dengan media pembelajaran yang diterapkan, siswa kurang fokus terhadap media yang dipakai. Maka dilakukan simakan kedua untuk hari berikutnya.

a. Kegiatan Awal

Pada kegiatan ini difokuskan pada kegiatan menjelaskan unsur cerita. Kegiatan ini diawali dengan :

1 Guru mengadakan presensi untuk mengetahui kehadiran siswa melalui grup Whattsapp

\section{b. Kegiatan Inti}

Pada kegiatan ini setelah pemberian motivasi kemudian guru menjelaskan materi tentang unsurunsur dari suatu cerita.Kemudian guru memberikan link satu cerita yang ada di Youtube dengan judul "Malin Kundang" Siswa menyimak cerita tersebut melalui Hp masingmasing.Kemudian guru memberikan soal mengenai unsur cerita.Siswa mengerjakan soal dalam rentang waktu.Jawaban dikirim melalui pesan Whatssapp. Guru melakukan pembahasan soal.

c. Kegiatan Penutup

Guru melakukan refleksi dan memberikan simpulan mengenai cerita Malin Kundang.

Ketuntasan Belajar Siswa

Siswa memiliki motivasi tinggi dan konsentrasi tinggi untuk menyimak sebuah cerita. Mengamati dari pembahasan tersebut diatas, peneliti menyimpulkan bahwa media youtube dapat meningkatkan kemampuan menyimak cerita bagi siswa kelas III SD Muhammadiyah Karangharjo Yogyakarta. Sebagai bukti adalah paparan nilai menyimak hasil observasi pada simakan 1 nilai rata-ratanya adalah 73,5, kemudian naik menjadi 80,55 pada simakan II. Pada simakan ke II ini sudah ada peningkatan yang maksimal. Berarti dapat dikatakan bahwa seluruh siswa ada peningkatan yang sangat baik.

$$
\text { Dengan demikian }
$$
pembelajaran menyimak dengan menggunakan media youtube dapat dikatakan efektif diajarkan karena dapat memberikan motivasi kepada siswa untuk belajar menyimak dengan baik dan memberikan siswa suatu pengalaman baru dalam 
belajar sehingga siswa lebih tertarik dalam belajar.

\section{SIMPULAN}

Mengamati dari hasil nilai tersebut diatas, peneliti menyimpulkan bahwasanya media youtube merupakan salah satu alternatif yang dapat digunakan untuk meningkatkan kemampuan menyimak cerita pada siswa kelas III SD Muhammadiyah Karangharjo Yogyakarta.

\section{DAFTAR PUSTAKA}

Arikunto, Suharsimi. (2010). Prosedur Penelitian : Suatu Pendekatan Praktek. Jakarta : Rineka Cipta.

Damayanti, Rini. (2010). Keefektifan Penggunaan Siaran Televisi dan Radio dalam Pembelajaran Keterampilan Menulis Berita Peserta Didik SMP. S2 Thesis. UNY. 